http://dx.doi.org/10.11646/zootaxa.3925.4.7

http://zoobank.org/urn:lsid:zoobank.org:pub:BD0F23A9-3AE5-48F0-991B-EDAEC7C42FEC

\title{
New species and new records of bryozoans from shallow waters of Madeira Island
}

\author{
JAVIER SOUTO ${ }^{1,2}$, MANFRED J. KAUFMANN $^{3,4,5} \&$ JOÃO CANNING-CLODE $^{6,7,8}$ \\ ${ }^{1}$ Institut für Paläontologie, Geozentrum, Universität Wien, Althanstrasse 14, A-1090, Wien, Austria. E-mail: javier.souto@usc.es \\ ${ }^{2}$ Departamento de Zoología y Antropología Física. Universidad de Santiago de Compostela \\ ${ }^{3}$ University of Madeira, Centre of Life Sciences, Marine Biology Station of Funchal, 9000-107 Funchal, Madeira, Portugal \\ ${ }^{4}$ CIIMAR/CIMAR (Interdisciplinary Centre of Marine and Environmental Research), University of Porto, Rua dos Bragas 289, 4050- \\ 123 Porto, Portugal \\ ${ }^{5}$ CIIMAR - Madeira (Interdisciplinary Centre of Marine and Environmental Research of Madeira), Edificio Madeira Tecnopolo, \\ Caminho da Penteada, 9020-105 Funchal, Madeira, Portugal \\ ${ }^{6}$ MARE-Marine and Environmental Sciences Centre, Estação de Biologia Marinha do Funchal, Cais do Carvão 9000-107 Funchal, \\ Madeira, Portugal \\ ${ }^{7}$ Centre of IMAR of the University of the Azores, Department of Oceanography and Fisheries, Rua Prof. Dr Frederico Machado, 4, PT- \\ 9901-862 Horta, Azores, Portugal \\ ${ }^{8}$ Smithsonian Environmental Research Center, Edgewater, MD 21037
}

\begin{abstract}
Two new species of bryozoans encrusting subtidal rocks are described from the shallow waters of Madeira Island. We describe one cyclostome, Favosipora purpurea sp. nov., which represents the first record of this genus in the Atlantic Ocean, and one cheilostome, Rhynchozoon papuliferum sp. nov. In addition, one species, Beania maxilladentata, is recorded for the first time outside of Rio de Janeiro, Brazil. Six other species previously recorded in Madeira are redescribed to provide new data and SEM images.
\end{abstract}

Key words: Bryozoa, Madeira, Beania, Favosipora, Hippoporella, Rhynchozoon, new species, taxonomy

\section{Introduction}

Until very recently, knowledge about the bryozoan fauna of Madeira Island was scarce and mainly documented in pioneer taxonomic works published at the end of the $19^{\text {th }}$ and early $20^{\text {th }}$ centuries (Busk 1858a,b, 1859, 1860, 1861; Hincks 1880; Johnson, 1897; Waters 1899; Norman 1909). However, a few scientific papers have been published in recent years using modern techniques such as scanning electron microscopy (SEM), contributing to better knowledge of bryozoans of this island (d'Hondt 1985; Alves \& Cocito, 2002; Berning \& Kuklinski 2008; Berning et al. 2008; Wirtz \& Canning-Clode, 2009; Berning 2012, Souto et al., 2014). Berning (2012) listed 140 species of cheilostome bryozoans in Madeira and considered the island a 'hotspot' for bryozoan diversity when compared to other nearby regions. In fact, this observed increase in bryozoan biodiversity in recent years may be linked to two factors. First, the evolution from the use of optical microscopy in the older studies to the more recent era of SEM has revealed that several species were given names of existing, somewhat similar-looking species from elsewhere (Berning 2012). These new taxonomic techniques indicated that many species previously identified as 'foreign' were, in fact, distinct species, several being endemic to Madeira (Berning \& Kuklinski 2008; Berning et al. 2008). Second, monitoring in marinas and harbours for non-indigenous species in recent years has also detected new invasive bryozoans (Wirtz \& Canning-Clode 2009; Canning-Clode et al. 2013).

In the present paper we describe two new species of Bryozoa collected on rocks from a small islet located on the south coast of Madeira. We further describe seven other bryozoan species found in these samples, either previously unknown or little known in Madeira Island. 
Waters (1899) noted that his Madeiran specimens differed from $R$. bispinosum in several respects, recording them as 'Rynchozoon bispinosa var.' but not formally naming the variety. According to his account, these specimens were characterized by the presence of "very numerous small, papilliform avicularia scattered over the surface," with a slit-like opening under the mandible smaller than the mandible. We have examined the original specimens from Waters' collection kept at the Manchester Museum (MM-5306, MM-5307) and can confirm that those labelled as 'Rynchozoon bispinosum var.' are conspecific with our specimens.

\section{Acknowledgements}

We are grateful to Oscar Reverter-Gil, Paul Taylor and Linda McCann for helpful comments on an earlier version of this work. We also thank Kate Sherburn (MM) for the loan of material from the Waters collection and Filipe Henriques for assistance during SCUBA diving. Funding for J. Souto was provided by the Austrian FWF (Lise Meitner Program No M1444-B25). J. Canning-Clode was supported by a starting grant in the framework of the 2014 FCT Investigator Programme (IF/01606/2014). This is contribution number 27 of the Marine Biology Station of Funchal.

\section{References}

Álvarez, J.A. (1992) Sobre algunas especies de la familia Lichenoporidae Smitt, 1866 (Bryozoa, Cyclostomida) en la región Atlántico-Mediterranea: Parte I: género Disporella Gray, 1848. Cahiers de Biologie Marine, 33, 201-243.

Alves, F.M.A \& Cocito, S. (2002) A new bryozoan record (Bugula calathus minor) for the marine fauna of Madeira Island (NE Atlantic). Bocagiana, 204, 1-5.

Arístegui Ruiz, J. (1984) Briozoos Quilostomados (Ectoprocta, Cheilostomata) de Canarias: Estudio sistemático, faunístico y biogeográfico. $\mathrm{PhD}$ thesis, Universidad de La Laguna, España. [total page number unkown]

Berning, B., Tilbrook, K.J. \& Rosso, A. (2008) Revision of the north-eastern Atlantic and Mediterranean species of the genera Herentia and Therenia (Bryozoa: Cheilostomata). Journal of Natural History, 42, 1509-1547. http://dx.doi.org/10.1080/00222930802109140

Berning, B. \& Kukliński, P. (2008) North-east Atlantic and Mediterranean species of the genus Buffonellaria (Bryozoa, Cheilostomata): implications for biodiversity and biogeography. Zoological Journal of the Linnean Society, 152, 537-566. http://dx.doi.org/10.1111/j.1096-3642.2007.00379.x

Berning, B. (2012) Taxonomic notes on some Cheilostomata (Bryozoa) from Madeira. Zootaxa, 3236, $36-54$.

Bianchi, C.N., Morri, C., Sartoni, G. \& Wirtz, P. (1998) Sublitoral epibenthic communities around Funchal (Ilha da Madeira, NE Atlantic). Boletim do Museu Municipal do Funchal, 5, 59-80.

Borg, F. (1944) The stenolaematous Bryozoa. Further Zoological Results of the Swedish Antarctic Expedition 1901-1903, 3 (5), 1-276, 16 pls.

Busk, G. (1858a) Zoophytology. On some Madeiran Polyzoa. Quarterly Journal of Microscopical Science, 6, 124-130.

Busk, G. (1858b) Zoophytology. On some Madeiran Polyzoa. Quarterly Journal of Microscopical Science, 6, $261-263$.

Busk, G. (1859) Zoophytology. On some Madeiran Polyzoa. Quarterly Journal of Microscopical Science, 7, 65-67.

Busk, G. (1860) Zoophytology. Catalogue of the Polyzoa collected by J.Y. Johnson, Esq., at Madeira, in the years 1859 and 1860, with descriptions of new species. Quarterly Journal of Microscopical Science, 8, 213-214, 280-285.

Busk, G. (1861) Description of new Polyzoa collected by J.Y.Johnston Esq., at Madeira. Quarterly Journal of Microscopical Science, New Series, 1, 77-80.

Busk, G. (1875) Catalogue of Marine Polyzoa in the Collection of the British Museum. Part III. Cyclostomata. Trustees of the British Museum, London, $39 \mathrm{pp}$.

Busk, G. (1884) Report on the Polyzoa collected by H.M.S. Challenger during the years 1873-1876. Part 1. The Cheilostomata. Report on the Scientific Results of the Voyage of the H.M.S. "Challenger", Zoology, 10, 1-216.

Canu, F. (1917) Bryozoaires. Revue critique de Paléozoologie, 21, 29-37.

Canning-Clode, J., Fofonoff, P., McCann, L., Carlton, J.T. \& Ruiz, G. (2013) Marine invasions on a subtropical island: Fouling studies and new records in a recent marina on Madeira Island (Eastern Atlantic Ocean). Aquatic Invasions, 8, $261-270$. http://dx.doi.org/10.3391/ai.2013.8.3.02

Dick, M.H., Tilbrook, K.J. \& Mawatari, S.F. (2007) Diversity and taxonomy of rocky-intertidal Bryozoa on the Island of Hawaii, USA. Journal of Natural History, 40, 2197-2258. http://dx.doi.org/10.1080/00222930601062771

Gabb, W.M. \& Horn, G.H. (1862) The fossil Polyzoa of the Secondary and Tertiary Formations of North America. Journal of the Academy of Natural Sciences of Philadelphia, 5, 111-179.

Gordon, D.P. \& Taylor, P.D. (2001) New Zealand Recent Densiporidae and Lichenoporidae (Bryozoa: Cyclostomata). Species 
Diversity, 6, 243-290.

Gordon, D.P. \& Taylor, P.D. (2010) New seamount- and ridge-associated cyclostome Bryozoa from New Zealand. Zootaxa, 2533, 43-68.

Gordon, D.P. (2014) Favosipora MacGillivray, 1885. In: Bock, P. \& Gordon, D. (2014) World List of Bryozoa. Available from: http://www.marinespecies.org/aphia.php?p=taxdetails\&id=146811 (Accessed 3 November 2014)

Hayward, P.J. \& Ryland, J.S. (1995) The British species of Schizoporella (Bryozoa, Cheilostomatida). Journal of Zoology, 237, $37-47$. http://dx.doi.org/10.1111/j.1469-7998.1995.tb02744.x

Hayward, P.J. \& Ryland, J.S. (1999) Cheilostomatous Bryozoa. Part 2. Hippothoidea - Celleporoidea. Synopses of the British Fauna, New Series, 14, 1-416.

Hondt, J.-L. d' (1985) Brachiopodes et Bryozoaires (Musorstom II). Mémoires du Muséum National d'Histoire Naturelle, 133, $519-525$.

Hincks, T. (1877) On British Polyzoa. Part I. Annals and Magazine of Natural History, Series 4, 20, 212-218.

Hincks, T. (1880) Contributions towards a general history of the marine Polyzoa. Part I. Madeiran Polyzoa. Annals and Magazine of Natural History, Series 5, 6, 69-80.

Hincks, T. (1895) Index [to "Marine Polyzoa: contributions towards a general history”]. London, xi pp. [issued privately]

Johnston, G. (1838) A History of British Zoophytes. W. H. Lizars, Edinburgh, London \& Dublin, xii, 341 pp., 44 pls.

Johnston, G. (1847) A History of British Zoophytes. $2^{\text {nd }}$ Edition. Van Voorst, London, xvi, 488 pp., 74 pls.

Johnson, J.Y. (1897) New cyclostomatous Bryozoa found at Madeira. Annals and Magazine of Natural History, Series 6, 20, $60-65$.

Jullien, J. (1883) Bryozoaires. Espèces draguées dans l'Océan Atlantique en 1881. Bulletin de la Société Zoologique de France , 7, 497-529, pls. 13-17.

Lamouroux, J.V.F. (1812) Extrait d'un mémoire sur la classification des Polypiers coralligènes non entièrement pierreux. Nouveau Bulletin scientifique de la Société Philosophique, 3, 181-188.

Linnaeus, C. (1758) Systema naturae per regna tria naturae, secundum classes, ordines, genera, species, cum characteribus, differentiis, synonymis, locis. $10^{\text {th }}$ Edition. Laurentii Salvii, Holmiae, $824 \mathrm{pp}$.

MacGillivray, P.H. (1885) Descriptions of new, or little known, Polyzoa. Part VII. Transactions and Proceedings of the Royal Society of Victoria, 21, 92-99, 3 pls.

Norman, A. (1909) The Polyzoa of Madeira and neighbouring islands. Journal of the Linnean Society (Zoology), 30, $275-314$.

Ramalho, L.V., Muricy, G. \& Taylor, P.D. (2008) Taxonomy of Beania Johnston, 1840 (Bryozoa, Flustrina) from Arrial do Cabo, Río de Janeiro State, Brazil. Arquivos do Museu Nacional, 66, 499-508.

Reuss, A.E. (1848) Die fossilen Polyparien des Wiener Tertiärbeckens. Haidingers Naturwissenschaftlichen Abhandlungen, 2 , $1-109$.

Souto, J., Reverter-Gil, O. \& Fernández-Pulpeiro, E. (2010) Gymnolaemate bryozoans from the Algarve (southern Portugal): new species and biogeographical considerations. Journal of the Marine Biological Association of the United Kingdom, 90, 1417-1439. http://dx.doi.org/10.1017/S0025315409991640

Souto, J., Reverter-Gil, O. \& Ostrovsky, A.N. (2014) New species of Bryozoa from Madeira associated with rhodoliths. Zootaxa, 3795 (2), 135-151. http://dx.doi.org/10.11646/zootaxa.3795.2.3

Tompsett, S., Porter, J.S. \& Taylor, P.D. (2009) Taxonomy of the fouling cheilostome bryozoans Schizoporella unicornis (Johnston) and Schizoporella errata (Waters). Journal of Natural History, 43, 2227-2243. http://dx.doi.org/10.1080/00222930903090140

Toscano, F. \& Taylor, P.D. (2008) A new Early Miocene bryozoan, Favosipora ichnusae sp. nov. (Cyclostomata), from the Isili Limestone of Sardinia, Italy. Neues Jahrbuch für Geologie und Paläontologie Abhandlungen, 248, 301-308. http://dx.doi.org/10.1127/0077-7749/2008/0248-0301

Vieira, L.M., Migotto, A.E. \& Winston, J.E. (2010) Shallow-water species of Beania Johnston, 1840 (Bryozoa, Cheilostomata) from the tropical and subtropical Western Atlantic. Zootaxa, 2550, 1-20.

Vigneaux, M. (1949) Révision des Bryozoaires néogènes du Bassin d'Aquitaine et essai de classification. Mémoires de la Société Géologique de France, New Series, 28, 1-153.

Waters, A.W. (1899) Bryozoa from Madeira. Journal of the Royal Microscopical Society, 1899, 6-16. http://dx.doi.org/10.1111/j.1365-2818.1899.tb00139.x

Wirtz, P. (1995) Unterwasserführer Madeira, Kanaren und Azoren. Niedere Tiere. Stephanie Nagelschmid, Stuttgart, 247 pp.

Wirtz, P. \& Canning-Clode, J. (2009) The invasive bryozoan Zoobotryon verticillatum has arrived at Madeira Island. Aquatic Invasions, 4, 669-670.

http://dx.doi.org/10.3391/ai.2009.4.4.11 